\title{
The Exclusive Jurisdiction of Flag States: A Limitation on Pro-active Port States?
}

\author{
Arron N. Honniball* \\ PhD Candidate (UNIJURIS Research Group), Netherlands Institute for the Law \\ of the Sea, School of Law, Utrecht University, Utrecht, The Netherlands
}

\begin{abstract}
The loosely phrased, and undefined, 'exclusive flag state jurisdiction' principle of the United Nations Law of the Sea Convention Article 92, has arguably proved to be a red herring for states and academia, in its being raised as a limiting factor to extra-territorial prescription by non-flag states. This has extended to port state jurisdiction discussions, and was raised by analogy for aircraft, before the European Court of Justice, in relation to the limits of jurisdiction over high seas overflight. This paper argues for a limited scope to the term 'jurisdiction' in Article 92. It concludes that far from being a limiting factor, the principle of flag state exclusivity is solely concerned with the enforcement jurisdiction of states on the high seas. The increasing use of port state prescriptive jurisdiction, particularly those practices with extra-territorial effect, provides further evidence that this is the correct interpretation.
\end{abstract}

\section{Keywords}

exclusive flag state jurisdiction - port state jurisdiction - prescriptive jurisdiction LOSC - Article 92

\footnotetext{
* See http://unijuris.sites.uu.nl/. The research which resulted in this publication was funded by the European Research Council under the Starting Grant Scheme (Proposal 336230Unijuris). The author wishes to thank Professor Henrik Ringbom, Professor Cedric Ryngaert, Nelson F. Coelho, and the participants in the Seminar on Extraterritoriality in Port State Jurisdiction (Utrecht, December 2015) for their insightful comments.
} 


\section{Introduction}

Across the board, port states are increasingly interested in the conduct of visiting foreign vessels, prior to, and after, their time at port. Indeed, the role of port states in certain fields has been increasingly highlighted and strengthened by the international community, to the extent that we consider not only port states' rights, but a general duty, and push for legally binding minimum standards in the exercise of jurisdiction by 'responsible' port states. ${ }^{1}$ The focus of this duty can include extra-territorial resources, and thus elements of extraterritoriality in the state's prescription. ${ }^{2}$

However, as the extra-territorial nature of port state prescription expands, what limitations does international law propose, and what limitations are of relevance in port state discussions? Although port states can use flexibility and uncertainty in the scope of jurisdictional rights, such as 'territorial' jurisdiction, the limits of port state jurisdiction are further obscured through uncertainty in the law of the sea regime's general principles. The example examined here is 'exclusive flag state jurisdiction' ('EFSJ') on the high seas. Although it is a cornerstone of the law of the sea, the relationship between port state prescription and flag state exclusivity has been raised, but underdeveloped. This article attempts to provide the first theoretical review of that relationship, in order to assess if it is a limiting factor on expansive port state jurisdiction.

After briefly introducing state jurisdiction and the principle of EFSJ, the article reviews the possibility of EFSJ limiting extra-territorial port state jurisdiction. This can be seen in the literature and case law. The article then moves on to review the legal scope of 'exclusive', and 'jurisdiction', to demonstrate its inapplicability as a limitation on port state jurisdiction. EFSJ, as a matter of at-sea enforcement, is demonstrated through a systematic analysis of the United Nations Convention on the Law of the Sea (LOSC), state practice and a literature review. This is reaffirmed through an examination of the intertwined LOSC Article 97 and the freedoms of the sea which EFSJ was developed to protect. The conclusion then summarises the findings, and highlights the meaning of these results for the future of port state jurisdiction.

1 Agreement on Port State Measures to Prevent, Deter and Eliminate Illegal, Unreported and Unregulated Fishing (Rome, 22 November 2009, in force 5 June 2016) (PSMA), [2010] ATNIF 41.

2 The broad 'elements of extra-territoriality' captures both extra-territorial prescription, and expansive 'territorial' prescription with extra-territorial effects; which are only separated by the determination of what territorial jurisdiction encompasses. 


\section{Port State Prescription and Flag State Exclusivity: A Clash of Principles?}

\section{State Jurisdiction}

In international law a state must have the legal capacity to act, and a legitimate interest in exercising jurisdiction. ${ }^{3}$ As extensively discussed and defined in the literature, it is evident that three distinct bundles of rights compose the concept of state jurisdiction:

Prescriptive jurisdiction: "to prescribe, i.e., to make its law applicable to the activities, relations, or status of persons, or the interests of persons in things, whether by legislation, by executive act, or order, by administrative rule or recognition, or by determination by a court". 4

Adjudicative jurisdiction: "to adjudicate, i.e., to subject persons or things to the process of its courts or administrative tribunals, whether in civil or in criminal proceedings, whether or not the state is a party to the proceedings" 5

Enforcement jurisdiction: "to enforce or compel compliance or to punish noncompliance with its laws or regulations, whether through the courts or by use of executive, administrative, police, or other nonjudicial action". 6

Each form of state jurisdiction is distinct. They are subject to different tests and differ in scope, through different internationally accepted grounds for establishing 'sufficient connections'. Legitimate prescriptive jurisdiction may exist for a state in relation to a particular form of conduct, but not for concurrent adjudicative ${ }^{7}$ or enforcement jurisdiction. ${ }^{8}$ The valid basis for one form

3 "The creation of a legal right is an act of the law; and the law can act only in accordance with itself. The power of a sovereign, therefore, to affect legal rights depends upon the law; and upon the law must be based all sovereign jurisdiction," J Beale, "The Jurisdiction of a Sovereign State' (1923) 36 Harvard Law Review 241-262, at p. 241.

4 American Law Institute, Restatement (Third) Foreign Relations Law of the United States (1987) at $\S 401(\mathrm{a})$.

5 Ibid., at $\S 401(\mathrm{~b})$.

6 Ibid., at $\S 401(\mathrm{c})$.

7 C Ryngaert, Jurisdiction in International Law (2nd ed., Oxford University Press, Oxford, 2015) at p. 10.

8 K Hixson, 'Extraterritorial Jurisdiction Under the Third Restatement of Foreign Relations Law of the United States' (1988) 12 Fordham International Law Journal 127-152, at p. 130, referring to the 'Second Restatement, § 7'. 
of jurisdiction cannot, in and of itself, justify the existence of another form. This is not to say, however, that each doctrine is completely independent, but simply that each form must be established by its own international legal criteria. For example, a port state's enforcement jurisdiction for a particular law also depends on its jurisdictional right to first prescribe said law. ${ }^{9}$ In practice therefore, any limitations on prescription will also operate to limit enforcement. ${ }^{10}$

For the purposes of this discussion, port state jurisdiction refers to prescriptive jurisdiction enforced against foreign vessels in port. ${ }^{11}$ Flag state jurisdiction refers to jurisdiction exercised by a state, "whose flag the ship flies and is entitled to do so under UNCLOS", 12 over that said vessel. The concern here is jurisdictional rights, not responsibilities.

\section{A Clash of Principles: Port State Prescription on the High Seas}

Let us assume a port state wishes to exercise prescriptive jurisdiction over extra-territorial conduct by a foreign vessel or its crew. Jurisdiction law provides which states could exercise jurisdiction and on what grounds. The right to exercise jurisdiction necessarily also entails the obligation to recognise the rights of other states to exercise jurisdiction. Three options present themselves. First, a port state may use its extensive territorial jurisdiction, and the controversial concept of 'territorial extension', to indirectly alter the conduct through regulation of a territorial element, whilst 'taking into account' the extra-territorial conduct. ${ }^{13}$ Alternatively, a port state may rely on an accepted head of extra-territorial jurisdiction, namely another nexus

\section{$9 \quad$ Ibid.}

10 Ibid.

11 Generally: EJ Molenaar, 'Port State Jurisdiction' (2009) Max Planck Encyclopaedia of Public International Law, at para. 1.

12 GK Walker, Definitions for the Law of the Sea: Terms Not Defined by the 1982 Convention (Martinus Nijhoff Publishers, Leiden, 2012), at p. 193. The conditions of the United Nations Convention on the Law of the Sea (Montego Bay, 10 December 1982, in force 16 November 1994) (LOSC) 1833 UNTS 3, Articles 90-92, are beyond this article. Generally: R Barnes, 'Flag States' in DR Rothwell, AG Oude Elferink, KN Scott, and T Stephens (eds), The Oxford Handbook of the Law of the Sea (Oxford University Press, Oxford, 2015) 304-324.

13 Territorial jurisdiction encompasses the subjective, objective, effects and territorial extension doctrines. Functional/quasi-territorial jurisdiction (e.g., Exclusive Economic Zone (EEZ), Exclusive Fisheries Zone (EFZ), and Continental Shelf (CS)), is considered here to be coastal state prescription, with in-port enforcement. E.g., LOSC Article 220(1). Territorial 'extension': J Scott, 'Extraterritoriality and Territorial Extension in EU Law' (2014) 62 American Journal of Comparative Law 82-126. 
(nationality [active, flag, passive] and protective jurisdiction), universal jurisdiction, or a treaty-based allocation of jurisdiction through consent. ${ }^{14}$ Finally, a port state may go beyond what is currently acceptable in order to stimulate legal evolution, or simply because its self-interest in regulation is greater than the possible acts of retribution by other states.

However, whilst international law operates to avoid conflict through the allocation of jurisdiction, ${ }^{15}$ the same could be said of further recognised legal limitations on the exercise of jurisdiction. These limitations provide other scenarios where a state may have prima facie jurisdiction, but the international community has agreed that in a particular legal field, jurisdiction should be further limited to particular states. Limitations may flow from general principles of jurisdiction (such as reasonableness), ${ }^{16}$ but certainly, and additionally, from various sources of primary obligations (such as the law of the sea). ${ }^{17}$ Let us consider one limitation to extra-territorial port state jurisdiction that has been raised in jurisprudence and the academic literature, i.e., the exclusive jurisdiction of the flag state on the high seas and, subject to LOSC Article 56, the exclusive jurisdiction of the flag state in the Exclusive Economic Zones (EEZ): ${ }^{18}$ "Ships shall sail under the flag of one State only and, save in exceptional cases expressly provided for in international treaties or in this Convention, shall be subject to its exclusive jurisdiction on the high seas." 19

What is the legal relationship between extra-territorial prescriptive jurisdiction by port states and the principle of EFSJ on the high seas? More importantly, could they conflict, or are they mutually exclusive? The mere fact that a law is only applied and enforced in port does not answer this question, and

\footnotetext{
14 E.g., LosC, Article 218.

15 R Higgins, Problems and Process: International Law and How We Use It (Oxford University Press, Oxford, 1994), at p. 56 .

16 Admittedly, its legal status is debatable; Ryngaert ( $\mathrm{n} 7$ ) at p. 5 .

17 AT Gallagher and F David, The International Law of Migrant Smuggling (Cambridge University Press, New York, 2014), at p. 249.

18 LOsC Article 58(2). See The Arctic Sunrise Arbitration (Netherlands v. Russia), Award on the Merits, PCA Case No. 2014-02, at p. 55, para. 231, available at http://www.pcacases. com/web/sendAttach/1438, accessed 30 May 2016; M Nordquist, S Nandan and S Rosenne, United Nations Convention on the Law of the Sea, 1982: A Commentary (Martinus Nijhoff Publishers, The Hague, 1995), at pp. $3^{2-34}$.

19 LosC Article 92(1). See Convention on the High Seas (Geneva, 29 April 1958, in force 30 September 1962) ('HSC') 450 UNTS 11, Article 6, and drafting history (below).
} 
one must be careful to distinguish prescription and enforcement. ${ }^{20}$ "Maritime law enforcement action is premised upon the assertion of jurisdiction over the vessel or aircraft in question. Jurisdiction, in turn, depends upon the nationality, the location, the status, and the activity of the vessel or aircraft over which maritime law enforcement action is contemplated". ${ }^{21}$ When the activity and its location refer to the high seas, a possible clash arises, and it is to a few examples we now turn.

\section{Academic Literature Hinting at a Conflict of Jurisdictional Principles}

The exercise of extra-territorial port state jurisdiction over high seas conduct could be raised in discussions on multiple maritime zones. Port enforcement would occur in internal waters (territory), ${ }^{22}$ but the prescription would be applicable to the high seas. ${ }^{23}$ We shall therefore look to EFSJ being raised as a limitation on non-flag prescription in the high seas generally, and as a limitation specifically applicable to port states.

\section{Prescriptive Jurisdiction on the High Seas: An Approach to Exclusive Flag State Jurisdiction as a Non-flag Limitation}

Apart from the exceptional cases that are expressly provided for in international law (discussed below), vessels on the high seas are exclusively subject to flag state 'jurisdiction'. The first situation in which EFSJ presents a difficulty is therefore with an interpretation in accordance with the ordinary meaning

20 "The fact that a foreign vessel has voluntarily entered a port does not make internationally-questionable legislation enforceable against the foreign vessel." T McDorman, 'Port State Enforcement: A Comment on Article 218 of the 1982 Law of the Sea Convention' (1997) 28 Journal of Maritime Law \& Commerce 305-322, at p. 314. For a critique of the ECJ's failure to do so in the port context: G Baere and C Ryngaert, 'The ECJ's Judgment in Air Transport Association of America and the International Legal Context of the EU's Climate Change Policy' (2013) 18 European Foreign Affairs Review 389-410, at p. 406.

21 JA Roach and RW Smith, Excessive Maritime Claims (3rd ed., Martinus Nijhoff Publishers, Leiden, 2012), at p. 559 .

22 Convention on the Territorial Sea and the Contiguous Zone (Geneva, 29 April 1958, in force 10 September 1964) 516 UNTS 205, Article 5; LOSC Article 8.

23 Losc Article 86. The freedoms and jurisdictional conflict, discussed below, expand to the EEZ of foreign states, and should the port state also be the applicable coastal state, extra-territorial jurisdiction exercised within the EEz waters, beyond the sovereign rights and interests granted by LOSC Part v. For simplicity this article refers to the high seas. 
of 'jurisdiction', and in the context of a treaty that distinguishes between prescriptive and enforcement jurisdiction, when necessary and evident. ${ }^{24}$ The LosC and the Convention on the High Seas (HSC) would thus include prescriptive jurisdiction in that jurisdictional principle. For example, Doris König states:

$[\mathrm{O}] \mathrm{n}$ the high seas, vessels are subject to the exclusive jurisdiction and control of the flag State. This rule of customary international law is codified in Article 92(1) UN Convention on the Law of the Sea. As a rule, other States have no right to exercise prescriptive, enforcement, and adjudicative jurisdiction over foreign ships on the high seas. ${ }^{25}$

The exceptions of customary and treaty law are contained in those treaty provisions (where the flag state is a state party), or in the LOsc. ${ }^{26} \mathrm{~A}$ similar position can be found in the literature by, e.g., Churchill and Lowe, ${ }^{27}$ Pozdnakova, ${ }^{28}$

24 Vienna Convention on the Law of Treaties (Vienna, 23 May 1969, in force 27 January 1980) 1155 UNTS 331, Article 31(1); reflective of customary law. E.g., prescription: LOSC Articles 21 and 42, enforcement: Articles 73, 213-222.

25 D König, 'Flag of Ships' (2009) Max Planck Encyclopaedia of Public International Law, at para. 25 .

26 Ibid., at paras. 26-29. See further, "under traditional law of the sea only the flag State could exercise enforcement jurisdiction in respect of violations of international rules and regulations on the high seas. Under the 1982 Law of the Sea Convention, coastal and port States have been entrusted with certain enforcement powers in order to supplement flag State enforcement which is often insufficient." D König, 'The Enforcement of the International Law of the Sea by Coastal and Port States' (2002) 62 ZaöRV 1-16, at p. 14 .

27 "In general, the flag State [...] has the exclusive right to exercise legislative and enforcement jurisdiction over its ships on the high seas". RR Churchill and AV Lowe, The Law of the Sea (3rd ed., Manchester University Press, Manchester, 1988), at pp. 208-209. Exceptions discussed are treated as exceptions of enforcement and prescription; ibid., at pp. 209-212.

28 Article 92 "may be understood [...] as precluding States from enacting criminal laws directed against foreign ships where the legislation's geographical scope extends onto the high seas". A Pozdnakova, Criminal Jurisdiction over Perpetrators of Ship-Source Pollution: International Law, State Practice and EU Harmonisation (Martinus Nijhoff Publishers, Leiden, 2012), at p. 79. However, she later concludes: "In this author's view, UNCLOS does not generally preclude States from exercising prescriptive jurisdiction over foreign perpetrators of pollution on the high seas. Domestic laws examined [...] indicate uncertainty however as to the limits of States' prescriptive jurisdiction"; ibid., at p. 84 . 
Ronzitti, ${ }^{29}$ Hoffmann, ${ }^{30}$ and McDorman, ${ }^{31}$ amongst others. ${ }^{32}$ The principle can also be dealt with in a rather confusing manner, lacking clarity on the 'jurisdiction' discussed. ${ }^{33}$ Whilst other principles of extra-territorial

29 N Ronzitti, "The Enrica Lexie Incident: Law of the Sea and Immunity of State Officials Issues' (2013) 22 The Italian Yearbook of International Law Online 1-22, at p. 14. AJ Hoffmann, 'Freedom of Navigation' (2011) Max Planck Encyclopaedia of Public International Law, at para. 22.

31 "[A]ctivities of vessels on the high seas are governed exclusively by the law of the vessel's flag. Prima facie, arrival of a foreign vessel in port does not alter this situation," McDorman (n 20), at p. 313. "On the high seas, as a result of the exclusivity of flag state jurisdiction over a vessel, all vessels, including sovereign immune vessels, are "immune" from the prescriptive jurisdiction of other states except where there are treaty obligations to the contrary". T McDorman, 'Sovereign Immune Vessels: Immunities, Responsibilities and Exemptions' in H Ringbom (ed), Jurisdiction over Ships: Post-UNCLOS Developments in the Law of the Sea (Brill, Leiden, 2015) 82-102, at p. 95.

32 NM Hosanee, A Critical Analysis of Flag State Duties as Laid down under Article 94 of the 1982 United Nations Convention on the Law of the Sea, available at http://www.un.org/ depts/los/nippon/unnff_programme_home/fellows_pages/fellows_papers/hosanee_og10 _mauritious.pdf; accessed 2 February 2015, at 16-17. DS Calley, Market Denial and International Fisheries Regulation: The Targeted and Effective Use of Trade Measures against the Flag of Convenience Fishing Industry (Martinus Nijhoff Publishers, Leiden, 2011), at p. 77; exclusive prescriptive and enforcement jurisdiction (Article 92), but subsequent discussions focus on exceptions to exclusive enforcement only; ibid., at pp. 77-83. L Bautista, 'The Role of Coastal States', in R Warner and S Kaye (eds), Routledge Handbook of Maritime Regulation and Enforcement (Routledge, London, 2015) 59-70, at p. 65. In 'State Jurisdiction on the High Seas', the EFSJ focuses on enforcement options, but similarly quotes Churchill and Lowe on exceptions of a legislative nature; PHG Vrancken, South Africa and the Law of the Sea (Martinus Njjhoff Publishers, Leiden, 2011), at pp. 209-210. On general extra-territorial legislative jurisdiction, the lack of territorial jurisdiction means "international law allows or requires States to exercise either functional jurisdiction or flag State jurisdiction", ibid., at p. 49 (despite discussing counter South African practice; ibid., at pp. 51-52).

33 In 'Jurisdiction over Vessels Given to States Other than the Flag State', it is stated that states may be granted enforcement or prescriptive jurisdiction-but the examples are of enforcement; A Bardin, 'Coastal State's Jurisdiction over Foreign Vessels' (2002) 14 Pace International Law Review 27-76, at pp. 46-48. Later, "Finally, on the high seas, UnCLOS provides only for flag State jurisdiction regarding all high seas fishing activities undertaken by vessels flying their flag. Hence, the coastal States cannot take enforcement actions" (emphasis added); ibid., at p. 57. Bateman defines jurisdiction as inclusive of prescription, and "[o]nly the flag State may exercise jurisdiction over a vessel on the high seas with very limited exceptions"; but yet again the 'limitations on flag State jurisdiction' only concern enforcement. The same can be seen in the conclusions, where EFSJ "may come to be undermined by increasing regulation of activities on the high seas"-[regulation a 
prescriptive jurisdiction are raised, including nationality (Churchill and Lowe $)^{34}$ and effects/protective jurisdiction (McDorman), ${ }^{35}$ the principle of EFSJ is treated as a consideration, whose 'sanctity' should be considered, and dispelled, in the case at hand.

A principle is therefore suggested which can act as a limitation on otherwise valid non-flag prescription. This creates particular difficulties for incidents involving multiple vessels, flagged to different states, where clearly both cannot have exclusive jurisdiction. One suggestion reads Article 92 as providing exclusive jurisdiction, where one vessel is involved, but, subject to Article 97, allowing the validity of other jurisdictional bases in multiple vessel scenarios. ${ }^{36}$

The limitation role of flag state exclusivity has been more explicit in works on the general rules of jurisdiction. For example, The Cambridge Companion to International Law points to the disdain of negative conflicts of jurisdiction, to highlight the necessity of extra-territorial principles in areas lacking territorial jurisdiction-for which the high seas qualifies. ${ }^{37}$ However, after accepting the 'substantial link' process of allocating jurisdiction, the authors propose a second examination if:

[A] state's relation to a set of facts is so close, and its interests involved in it so important, that international law recognises it as the state with by far the closest link and thus endows it with exclusive jurisdiction over the matter. This might explain some of the normative choices made by

power of prescriptive jurisdiction], but again the examples refer to non-flag enforcement; S Bateman, 'The Role of Flag States', in Warner and Kaye (n 32) 43-58, at pp. 46-47, 53; Gallagher and David (n 17) at pp. 225, 242, 243-249 (discussing exclusive jurisdiction as both prescriptive and enforcement, or just enforcement).

34 Discussing the nationality principle in relation to collisions: "[T] he expectation is that in this case of concurrent jurisdiction it is the flag state whose jurisdiction has primacy (see, e.g., LOSC, Article 94)", Churchill and Lowe (n 27) at p. 209. See also unauthorised broadcasting and the nationality principle, ibid., at p. 211. As argued below, this expectation is one of comity, and not based on legal considerations of Article 92.

35 McDorman (n 20) at pp. 314, 320-322.

36 On prescription: "Article 92 is better understood as preventing states from exercising jurisdiction over events that take place entirely onboard a single ship on the high seas that bears the flag of another State." JW Davids, 'Jurisdiction and Diplomacy on the High Seas: India vs. Italy', The $\{\mathrm{New}\}$ International Law Blog (29.02.2012), available at https:// thenewinternationallaw.wordpress.com/2012/02/29/jurisdiction-and-diplomacy-on-thehigh-seas-india-vs-italy/, accessed 30 May 2016.

37 LOsC Article 89. B Simma and AT Müller, 'Exercise and Limits of Jurisdiction', in J Crawford and M Koskenniemi (eds), The Cambridge Companion to International Law (Cambridge University Press, Cambridge, 2012) 134-157, at p. 139. 
contemporary international law which provide, for example, for a state's exclusive jurisdiction as to [...] ships flying its flag. ${ }^{38}$

So Article 92 exclusivity "supersede[s] jurisdiction interests of other international actors", establishing the flag state as the chief basis. ${ }^{39}$ Recent work by Geiss and Tams also posits this as the 'traditional' normative achievement of the law of the sea. ${ }^{40}$ Whilst it can certainly be agreed that this conclusion could avoid confusion and insecurity in international relations, and provide some legal certainty to private actors, ${ }^{41}$ it is argued below that no such exclusivity of prescriptive jurisdiction should be taken from the principle codified in Losc. The 'jurisdiction' in 'exclusive flag state jurisdiction' provides neither a rebuttable presumption of exclusive prescription on the high seas, nor a limitation on otherwise valid extra-territorial prescription, because it is solely concerned with limiting enforcement at sea in the high seas/EEz. Whilst the enforcement nature of EFSJ is noticeable in its exceptions (see below), the unfortunate lack of an explicit reference to enforcement in the wording of Article 92 has misled the above interpretations into including a presumptive limitation on prescriptive jurisdiction-a wide and significant treaty-based departure from general prescriptive jurisdiction - that one would expect to be supported by conclusive practice, if not explicit wording. The lack of evidence for such a presumption should be telling.

\section{Enforcement in Port: An Approach to Exclusive Flag State Jurisdiction as a Port State Limitation}

EFSJ as inclusive of prescriptive jurisdiction has similarly led to the doctrine being raised in discussions on port state jurisdiction. The clearest extraterritorial example is LOSC Article 218, the exceptional and innovative treatybased jurisdiction over high seas pollution. Subject to the conditions imposed,

\footnotetext{
$38 \quad$ Ibid., at p. 149.

39 Ibid., at p. 150.

40 "[T]he flag links the ship to a particular state, and this link supersedes other links, including other traditional categories such as ownership or nationality of seafarers, or more recent grounds justifying assertions of jurisdiction in other fields such as effects or impact," R Geiss and CJ Tams, 'Non-Flag States as Guardians of the Maritime Order: Creeping Jurisdiction of Another Kind?', in Ringbom (n 31) 19-49, at p. 21. Admittedly, the discussion on drug enforcement cooperation then focuses back on EFSJ as an enforcement issue.

41 Ibid., at pp. 22-23.
} 
a port state may exercise limited prescriptive and enforcement jurisdiction over high seas conduct, to which it otherwise does not have a substantial link. Nevertheless, it is also suggested that "the conferral of concurrent enforcement jurisdiction over illegal discharges on the high seas on port States leads to a curtailment of the exclusive jurisdiction of flag States", ${ }^{42}$ or more generally that "there are subtle signs that 'exclusive' flag state jurisdiction is weakening from port state control". ${ }^{43}$ Extra-territorial port state jurisdiction would arguably only have an effect on flag state exclusivity if the latter doctrine included prescriptive exclusivity, as port state jurisdiction is by definition enforced territorially.

Port state jurisdiction has not only been raised as a limitation on exclusivity, or its 'excessive invocation', 44 but also vice-versa, as limited itself by Article 92. ${ }^{45}$ The argument that Article 218 not only provides a novel basis of jurisdiction, but also an implicit exhaustive code, presumably presupposes that otherwise exclusivity exists. ${ }^{46}$ This is later made more explicit: "there is a sanctity to flag State jurisdiction that operates to preclude port State authority over foreign vessels for activities on the high seas or in the waters of other States except in clearly defined circumstances." ${ }^{27}$ As supporting evidence, Bodansky states

42 König (n 25) at para. 35 .

43 J Kraska and R Pedrozo, International Maritime Security Law (Martinus Nijhoff Publishers, Leiden/Boston, 2013), at p. 365 (despite identifying EFSJ as a matter of enforcement). Viewing the relationship from the perspective of 'in' port: "Most scholars regard the authority of a port State over foreign-flagged vessels temporarily in the port to be superior to exclusive flag state jurisdiction" (fn. omitted) ibid., at pp. 413-414, further at p. 369 .

44 Whilst not a 'true' exception, port state jurisdiction "facilitate[s] concrete measures against its excessive invocation", Geiss and Tams (n 40) at p. 34.

45 The same can be seen in relation to other valid extra-territorial principles, Ronzitti (n 29) at 14-15, which whilst accepting concurrent Italian/Indian jurisdiction, suggests Article 92 provides exclusive Italian jurisdiction. Although later the opposite is raised: "Once the ship was within India's internal waters, India could claim its jurisdiction even though the ship was lured with a stratagem and the arrest was made in violation of international law"; ibid., at p. 16.

46 McDorman (n 20), at p. 321.

47 Ibid. Concluding "ratification of the LOS Convention and implementation of Article 218 will circumscribe a port State's ability to take enforcement action against foreign vessels voluntarily in port that have committed a discharge violation on the high seas or in the waters of another State. Under existing law, where the discharge violation affects the port State, enforcement action arguably could be taken. Pursuant to Article 218, the flag State or the State where the incident occurred can usurp the port State's"; ibid., at 322-323. But if that previous jurisdiction is based on the effects doctrine, and not on the novel Article 218, how is it to be subject to those limitations? 
"[d]uring the negotiation of MARPOL, proposals to allow port state enforcement of discharge violations on the high seas were defeated on the grounds that this would infringe on the flag state's high seas jurisdiction".48

More generally, EFSJ is considered as a possible basis of objection in the literature on residual port state jurisdiction. ${ }^{49}$ Discussions on emissions control by port states have raised potential objections similar to that of the ATAA case (see below). As highlighted by Ringbom:

Opponents of the scheme would argue that a regional ETS which covers emissions beyond the territory of the port State(s) challenges those principles. It impinges on the exclusive jurisdiction of non-EU flag States to regulate and enforce $\mathrm{CO}_{2}$ emissions for their ships. ${ }^{50}$

Ringbom himself concludes that port states are not prevented from implementing requirements that have implications beyond the port state's territorial jurisdiction, but the question remains whether this principle should even be considered in that balancing. Other authors have balanced the question the other way, ${ }^{51}$ or raised EFSJ as a discussion point, before rightfully focusing on the topical developments of PSJ. ${ }^{52}$

48 D Bodansky, 'Protecting the Marine Environment from Vessel Source Pollution: UNCLOS III and Beyond' (1991) 18 Ecology Law Quarterly 719-777, at p. 760.

49 Regulation by port states of vessel operations "arguably conflicts with the right of a vessel's operator to do as he wishes when outside the maritime zones of coastal states, based on the concept of freedom of navigation, and the exclusive jurisdiction of the flag state on the high seas". B Marten, Port State Jurisdiction and the Regulation of International Merchant Shipping (Springer, Heidelberg, 2010) at p. 62. See further 'bold' employment regulation and the possibility that flag states might object on the basis of EFSJ; ibid., at pp. 169, 210.

$5^{\circ}$ H Ringbom, 'Global Problem-Regional Solution-International Law Reflections on an EU $\mathrm{CO}_{2}$ Emissions Trading Scheme for Ships' (2010) 26 International Journal of Marine and Coastal Law 613-641, at p. 639 .

$51 \quad$ D Devine, 'Port State Jurisdiction: A Judicial Contribution from New Zealand' (2000) 24 Marine Policy 215-219, at pp. 218-219, welcoming the rejection of any customary law basis for extra-territorial PSJ on the basis that it would affect high seas activity.

$5^{2}$ "This right [Article 116] is safeguarded by the primacy of flag state jurisdiction on the high seas laid down in Articles 89 and 92(1), subject to various limited exceptions for at-sea enforcement, for instance those in Articles 109-111. The extent to which these safeguards affect the discretion of port states pursuant to Article 25(2) is at the heart of our discussion," EJ Molenaar, 'Port State Jurisdiction: Toward Comprehensive, Mandatory and Global Coverage' (2007) 38 Ocean Development \& International Law 225-257, at p. 233. Raised as an issue, but not delved into: NF Coelho, 'Extraterritoriality from the Port: 


\section{Case Law Reviewing Exclusive Flag State Jurisdiction as a Limitation on Non-flag State Prescription}

The possibility of EFSJ limiting the prescriptive jurisdiction of other states has not been limited to academic discussions. Despite being raised unsuccessfully as an argument before the Permanent Court of International Justice (PCIJ) in the 1927 SS Lotus case, it continues to be raised before the International Tribunal of the Law of the Sea, the European Court of Justice, and national courts..$^{53}$ Its sticking power as an issue of contention requires consideration.

\section{The SS Lotus (PCIJ)}

In a dispute concerning the collision of two vessels on the high seas, the French Government argued that it alone had exclusive jurisdiction that barred the exercise of objective territorial jurisdiction by the Turkish Government:

[A]rguments advanced by the French Government, other than those considered above, are, in substance, the three following: $[\ldots]$

(2) International law recognizes the exclusive jurisdiction of the State whose flag is flown as regards everything which occurs on board a ship on the high seas. ${ }^{54}$

In general, the PCIJ's reasoning on the right to extra-territorial prescriptive jurisdiction may now be dubious, whereby, unless restricted by a prohibitive rule, extra-territorial prescriptive jurisdiction is exercised as a matter of discretion. ${ }^{55}$ But it surely remains the correct approach to be applied to limitations on otherwise valid jurisdiction. Whilst one cannot presume a right that will infringe on the rights of other states (extra-territorial prescriptive jurisdiction), one may presume that, once established, that right is fully exercisable, subject only to explicit rules of limitation. After all, "limitation on sovereignty cannot be presumed". 56

EU's Approach to Jurisdiction over Ship-Source Pollution' (2015) 19 Spanish Yearbook of International Law 269-284, at pp. 275, 283.

53 See further cases settled prior to a decision being rendered, e.g., the Chilean port measures that 'hindered' high seas fishing (as claimed by the European Union). Molenaar implies that if more onerous port state measures were used, it might have been problematic for EFSJ and the freedom of fishing, Molenaar ( $\left.\mathrm{n}_{52}\right)$ at p. 238.

54 S.S. Lotus Case (France v. Turkey), (Ser. A) No. 10, at p. 22 (PCIJ, 1927).

55 Ibid., at p. 19.

56 Ibid., at p. 18. The M/V "Lousia" Case (Saint Vincent and the Grenadines v. Spain) (Provisional Measures), Order of 23 December 2010, Case No. 18, Dissenting Opinion of Judge Cot, at 
Two distinct rights must therefore be demonstrable: that flag states have a right to jurisdiction, and that this is exclusive, to the prohibition of all others. Whilst this could be demonstrated in regards to enforcement on the high seas, the French Government failed to demonstrate such a limitation on prescription. The conclusion thus remains applicable that:

Apart from certain special cases which are defined by international lawvessels on the high seas are subject to no authority except that of the State whose flag they fly [...] But it by no means follows that a State can never in its own territory exercise jurisdiction over acts which have occurred on board a foreign ship on the high seas [...] This conclusion could only be overcome if it were shown that there was a rule of customary international law which, going further than the principle stated above, established the exclusive jurisdiction of the State whose flag was flown. ${ }^{57}$

The PCIJ used a similar approach to reject the existence of a specific rule on exclusivity in regard to collisions. ${ }^{58}$ Whilst this may have been overturned in the specific case of collisions and 'incidents of navigation', 59 in regard to other situations the reasoning on limitations remains true. ${ }^{60} \mathrm{~A}$ valid prescriptive basis is equally valid on the high seas as any other part of the earth.

\section{The Enrica Lexie (Indian Supreme Court and ITLOS); (PCA Pending)}

The question of which state should exercise jurisdiction over maritime incidents continues to play out in international tribunals, as demonstrated by the ongoing Enrica Lexie dispute. Here Italian 'armed forces' personnel, on board an Italian vessel as part of a counter-piracy contingent, shot and killed two

p. 95, para. 16 (ITLOS 2010), available at https://www.itlos.org/fileadmin/itlos/documents/ cases/case_no_18_prov_meas/18_order_231210_dis_op_Cot_en.pdf, accessed 30 May 2016.

57 Lotus (n 54), at p. 25. The PCIJ continues (with examples): "On the other hand, there is no lack of writers who, on a close study of the special question whether a State can prosecute for offences committed on board a foreign ship on the high seas [...] the general rules of each legal system in regard to offences committed abroad are applicable", ibid., at pp. 26-27.

58 Ibid., at pp. $28-30$.

59 Infra (n 119).

60 M Akehurst, 'Jurisdiction in International Law' (1972) 46 British Year Book of International Law $145^{-257}$, at pp. 187-188. From a policy perspective, a limitation on otherwise valid jurisdiction would be equally questionable; Lotus (n 54), at pp. 30-31. 
Indian fishermen 'some' 20.5 nautical miles (nm) off the Indian coast. ${ }^{61}$ Both India and Italy claimed concurrent jurisdiction, with a further dispute on whether the Italian vessel was "by ruse or coercion" persuaded to go to Kochi port (i.e., whether extra-territorial enforcement jurisdiction was exercised by India). ${ }^{62}$

Before the Indian Supreme Court, the representative of the Italian marines and government appears to have unsuccessfully relied on an overly broad interpretation of Article 97 which would have included homicides in "incidents of navigation". ${ }^{63}$ To this mix was added flag state exclusivity, although without elaboration. Referring to the overruling practice that followed Lotus, ${ }^{64}$ this had:

overruled the application of the principles of concurrent jurisdiction over marine collisions. Mr. Salve urged that a reading of Article 91, 92, 94 and 97 of UNCLOS clearly establishes that any principle of concurrent jurisdiction that may have been recognised as a principle of Public International Law stands displaced by the express provisions of UNCLOS. ${ }^{65}$

61 Request under article 290, paragraph 5, of the Convention, submitted by Italy on 21 July 2015, Case No. 24, at p. 7, para. 30, available at https://www.itlos.org/fileadmin/itlos/ documents/cases/case_no.24_prov_meas/Request/Request_of_the_Italian_Republic_ r.pdf, accessed 30 May 2016. Disputed facts, as summarised, The "Enrica Lexie" Incident (Italy v. India), Provisional Measures, Order of 24 August 2015, Case No. 24, Declaration of Judge Ad Hoc Francioni, at p. 7, para. 22 (ITLOS 2015), available at https://www.itlos .org/fileadmin/itlos/documents/cases/case_no.24_prov_meas/C24_Order_24.08.2015_ decl_Francioni_orig_Eng.pdf, accessed 30 May 2016; R Yadava, 'Indian Supreme Court on Jurisdiction over the Italian Marines', International Law Curry Blog (06.04.2013), available at https://ilcurry.wordpress.com/2013/04/o6/indian-supreme-court-on-jurisdiction-overthe-italian-marines/, accessed 30 May 2016.

62 Notification Instituting Arbitral Proceedings Dated 26 June 2015, Case No. 24, at 10-12, para. 29, available at https://www.itlos.org/fileadmin/itlos/documents/cases/case_no.24_ prov_meas/Request/Notification_of_the_Italian_Republic_r.pdf, accessed 30 May 2016. Written Observations Submitted by India on 6 August 2015, Case No. 24, at p. 11, para. 2.3, available at https://www.itlos.org/fileadmin/itlos/documents/cases/case_no.24_prov_meas/ Response/VOL_1.pdf, accessed 30 May 2016.

63 Dismissed by the chief justice as the case was not an incident of navigation, although oddly and incorrectly Justice Chelameshwar states Article 97 would not apply within the EEZ; Yadava (n 6o).

64 Infra (n 119).

65 Republic of Italy \& Ors. v. Union of India \& Ors., Writ Petition (Civil) No. 135 Of 2012, at 43-44, para. 38 (Supreme Court of India 2013), available at http://judis.nic.in/ supremecourt/imgsi.aspx?filename=39941, accessed 30 May 2016. For a blogosphere 
In its claim before the ITLOS for provisional measures, Italy claimed India had breached the Losc by arresting and detaining the vessel, interfering with Italy's freedom of navigation and exercising jurisdiction over the incident "notwithstanding Italy's exclusive jurisdiction".66 Primary reliance is placed on its 'exclusive' jurisdiction, with Article 97 also still raised. The host of LOSC Articles apparently breached by India, as per Italy's claim, includes Article 92 on the exclusive jurisdiction of flag states. ${ }^{67}$ Unlike in Lotus, where France tried to claim exclusive prescriptive jurisdiction, Italy appears to be arguing that the exercise of enforcement by India has been limited by the LOSC, with only Italy having the right to take enforcement against extra-territorial crimes. ${ }^{68}$ This is not just exclusive enforcement jurisdiction on the high seas, but in relation to the high seas. ${ }^{69}$ This implies practical prescriptive exclusivity. At the time of the arrest, detention and commencement of criminal proceedings against the Italian marines, the vessel was in the port and therefore the territory of India. Nevertheless, Italy claimed:

supporter; "Article 92 of UNCLOS [...] is enough to preclude the application of the passive personality principle", Davids (n 36 ). No evidence is provided for such a farreaching and drastic reading of Article 92. Hollis, who focused on the limited nature of Article 97, provides more persuasive arguments for concurrent jurisdiction; D Hollis, 'The Case of Enrica Lexie: Lotus Redux?', Opinio Juris Blog (17.06.2012), available at http://opiniojuris.org/2012/o6/17/the-case-of-enrica-lexie-lotus-redux/, accessed 30 May 2016.

66 Request under article 290 (n 61) at p. 7, para. 30. For a previous protest by Italy and the crew: ibid., at 3-4, paras. 13-17; p. 5, paras. 20; 24.

67 "[N]otably Articles 2(3), 27, 33, 56, 58, 87, 89, 92, 94, 97, 100, and 300 of the Convention, and customary international law", Notification Instituting Arbitral Proceedings (n 62) at p. 10, para. 29 .

68 However: Notification Instituting Arbitral Proceedings (n 62) at p. 12, para. 29(h), appears to suggest that the exercise of extra-territorial prescriptive jurisdiction by India is a claim to sovereignty on the high seas and a violation in and of itself. It argues that the position is based on invalid coastal state jurisdiction, but does not seem to contemplate the Indian law being based on another extra-territorial principle, e.g., passive personality (The "Enrica Lexie" Incident (Italy v. India), Provisional Measures, Order of 24 August 2015, Case No. 24, at p. 11, para. 49 (ITLOS 2015), available at https://www.itlos.org/fileadmin/itlos/ documents/cases/case_no.24_prov_meas/C24_Order_24.08.2015_orig_Eng.pdf, accessed 30 May 2016: Indian claim "killing of its nationals").

69 Whilst discussing Sellers, Serdy's phraseology seems to be equally applicable to the Italian position: A Serdy, 'Changing Perspectives on the High Seas Freedom of Navigation?', in M Clarke (ed), Maritime Law Evolving (Hart Publishing Limited, Oxford, 2013) 23-41, at p. 27. 
By arresting, detaining, and exercising criminal jurisdiction over the Italian Marines, India violated and continues to violate Italy's right of exclusive jurisdiction to entertain criminal proceedings in connection with the Enrica Lexie incident and against the Italian Marines contrary inter alia to Article 92 of UNCLOS. The principle of exclusive jurisdiction of the flag State is derived inter alia from Articles 276, 56, 94, 97(1) and 97(3) of UNCLOS. ${ }^{70}$

As a ruling on provisional measures, the ITLOS order essentially repeats the different positions before concluding that there is a dispute on the interpretation and application of the Losc. ${ }^{71}$ As in the Indian Supreme Court case, reliance on Article 97 appears to be questionable, as it is rejected in the separate/ dissenting opinions. ${ }^{72}$ On the question of primary or exclusive jurisdiction, the correct interpretation of Article 92 as only referring to enforcement jurisdiction on the high seas would support the Indian position. ${ }^{73}$ Barring facts covered by express provisions, LOSC Part VII is silent on settling concurrent high seas jurisdictional claims enforced outside the high seas. ${ }^{74}$ This is left to

$70 \quad$ Notification Instituting Arbitral Proceedings (n 62) at p. 11, para. 29(e). Again support based on EFSJ; J Bellish, 'Revisiting jurisdiction over the Enrica Lexie incident', The View from above Blog (02.05.2016), available at http://jilp.org/1816/revisiting-jurisdictionover-the-enrica-lexie-incident/, accessed 30 May 2016, arguing that if it were not for the application of the Suppression of Unlawful Acts (SUA) Convention, Italy would have exclusive jurisdiction.

71 The "Enrica Lexie" Incident (Italy v. India), Provisional Measures, Order of 24 August 2015, (n 68), at p. 9, para. 38; Criticised, Dissenting Opinion of Vice-President Bouguetaia, Case No. 24, at p. 3, para. 13, available at https://www.itlos.org/fileadmin/itlos/documents/ cases/case_no.24_prov_meas/C24_Order_24.08.2015_diss.op_Bouguetaia_TR_Eng.pdf, accessed 30 May 2016.

72 Case No. 24; Dissenting Opinion Of Judge Ndiaye, at pp. 11-12, para. 25, available at https://www.itlos.org/fileadmin/itlos/documents/cases/case_no.24_prov_meas/C24_ Order_24.08.2015_diss_Ndiaye_TR_Eng.pdf, accessed 30 May 2016; Dissenting Opinion Of Judge Lucky, at p. 10, paras. 37-38, available at https://www.itlos.org/fileadmin/itlos/ documents/cases/case_no.24_prov_meas/C24_Order_24.08.2015_diss.op_Lucky_rev_ Eng.pdf, accessed 30 May 2016; Dissenting Opinion of Vice-President Bouguetaia (n 71) at p. 4, para. 14 (misinterpreting Article 97 as inapplicable within the contiguous zone).

73 Dissenting Opinion OfJudge Ndiaye (n 72 ) at 10-11, paras. 23-24.

74 "India maintains that ' $[\mathrm{t}]$ he only legal issue is to know what State... has the jurisdiction to try the perpetrators of this shooting, which led to the death of two Indian fishermen', and that '[o]n this point... Convention is silent"” The "Enrica Lexie" Incident (Italy $v$. India), Provisional Measures, Order of 24 August 2015 (n68) at p. 11, paras. 48-49. Dissenting 
general international law - which apart from a loosely formulated test of reasonableness also appears open to state discretion/cooperation. ${ }^{75}$

\section{Poulsen and ATAA (ECJ)}

The European Court of Justice (ECJ) adopted a position on EFSJ which incorporates prescriptive jurisdiction, most notably in the Poulsen decision. ${ }^{76}$ The relevant question raised was whether a technical fisheries measure in a European Council regulation could be applied to nationals of a European Member State aboard a foreign-(Panama)flagged vessel, or to the vessel itself whilst on the high seas. Whilst proposing the 'unlimited' jurisdiction of port states for territorial or coastal zone violations, the disputed provision would not be applicable to foreign vessels on the high seas, as "in principle such a vessel is there only governed by the law of the flag". ${ }^{77}$ Despite the discussion, no evidence or reasoning for such an interpretation of the EFSJ principle is presented.

Additionally, the Advocate General applied an even wider interpretation of EFSJ, limiting legislation with an extra-territorial effect on high seas conduct. In a similar manner to the ECJ, a "prohibition must be imposed by the flag State, whose legislation is exclusively applicable to the activities of the vessel on the high seas". ${ }^{78}$ However, the retention on board of fish caught on the high seas is so intimately linked to the high seas fishing itself, that rules prohibiting the retention on board whilst crossing the coastal state maritime zones, or entering the port, would also be prohibited. ${ }^{79}$

Although not in a case on the law of the sea, this argument resurfaced, by analogy, in the ATAA case, where an emissions trading scheme (ETS) would apply to all flights arriving or departing in the European Union (EU)

Opinion Of Judge Lucky (n 72) at 9-10, paras. 35-38; the LOSC does not contemplate or provide for the situation in the case, and Articles 92, 94 and 97 are simply not applicable.

75 For a good summary of the different positions: Dissenting Opinion Of Judge Ndiaye ( $\left.\mathrm{n}_{72}\right)$ at p. 5, para. 19 and H Sankar, 'Jurisdictional and Immunity Issues in the Story of Enrica Lexie : A Case of Shoot \& Scoot turns around!', Ejil:Talk! Blog (25.03.2013), available at http://www.ejiltalk.org/jurisdictional-and-immunity-issues-in-the-story-of-enrica-lexiea-case-of-shoot-scoot-turns-around/, accessed 30 May 2016.

76 Anklagemyndigheden $v$ Poulsen and Diva Navigation Corporation, Case C-286/9o [19992] ECR I-6o19.

77 Ibid., at p. I-6056, para. 22.

78 Opinion of Advocate General Tesauro, 31 March 1992, Case C-286/9o, at p. I-6039, para. 7 . Further, at I-6037-6038, para. 6; I-6040-6042, para. 9 .

79 Ibid., at I-6042-6045, paras. 10-12. 
territory. ${ }^{80}$ Thus it could take into account emissions throughout the flight, including over the high seas. The claimants suggested, by analogy to vessels, that "aircraft overflying the high seas are subject to the exclusive jurisdiction of the country in which they are registered, save as expressly provided for by international law". ${ }^{11}$ Given that this ETS would have been enforced in the EU territory, this claim must have rested on an interpretation of exclusive prescriptive jurisdiction. Although the Advocate General rejected this argument for lack of evidence, (indeed Germany, France, the UK and Norway all disputed such a principle for aircraft in customary law), the Advocate General accepted this exclusivity insofar as vessels are concerned. ${ }^{82}$ The clear distinction in treatment between ships and aircraft in the codified law of the sea led the Advocate General to dismiss EFSJ as irrelevant for customary aviation law. The ECJ, in one paragraph, took a similar approach, referring to Poulsen. ${ }^{83}$ Although not explicit on whether it was discussing enforcement or prescription, the fact that no high seas enforcement is at issue, and the positive reference to Poulsen, suggest the ECJ was including prescription in its discussion. Otherwise, the distinction between an infringement of EFSJ and the question of a customary basis to exercise jurisdiction makes little sense.

\section{Sellers (Australian Court of Appeal)}

In the port state literature, the case of Sellers $v$ Maritime Safety Inspector ${ }^{84}$ has received great attention. Briefly summarized, unilateral radio and emergency equipment conditions were imposed on vessels (including foreign-flagged vessels) departing from port for any place "outside" New Zealand. ${ }^{85}$ The Court of Appeal quashed the conviction of Mr Sellers for a failure to comply, as, amongst others, the construction, design, equipment and manning (CDEM) standards legislation was "to have an effect on the high seas", contrary to EFSJ. This is not only extra-territorial prescription being prohibited, but extra-territorial effects prescription. The decision has been heavily criticised for its interpretation of LOSC Articles 25, 211, and the territorial nature of the

\footnotetext{
8o Air Transport Association of America and Others $v$ Secretary of State for Energy and Climate Change (ATAA) Case C-366/10 [2012] oJ C49/7.

81 Opinion of Advocate General Kokott, 6 October 2011, Case C-366/10, at I-13806-13807, para. 127 .

82 Ibid., at p. I-13807, para. 128.

$83 \quad$ ATAA (n 80) at p. I-13886, para. 106.

84 [1999] 2 NZLR 44.

851994 Maritime Transport Act, Section 21, quoted in Serdy (n 69) at p. 26.
} 
port state jurisdiction. ${ }^{86}$ But critique has not focused on the Court's understanding of $\mathrm{EFSJ}^{87}$ which, as is evident below, is also arguably incorrect.

\section{Why Should This Theoretical Clash Be Settled?}

As can be seen, attempts to grapple with the question of port state extraterritoriality and the EFSJ principle raise various jurisdictional questions. These can be grouped into three general inquiries:

A. Does EFSJ operate as a legal limitation on the prescriptive jurisdiction of ports, or is it a historical preference for only flag states extending their laws to vessels on the high seas, and thus a matter of waning comity?

B. From the flag state perspective, are their rights being 'diluted', 'eroded' or subjected to 'creeping' jurisdiction by port states, as some suggest, or, again, is it only the facts on the ground that are changing as more states exercise concurrent jurisdiction?

C. The international community as a whole, and not just flag states, have a stake in the balance of interests, and jurisdictional balance that is established by the Losc. ${ }^{88}$ As port states push the boundaries of what is 'territorial', are they straining the boundaries of the law of the sea, with the division of maritime zones and distinct jurisdictional principles, such as flag state exclusivity?

86 B Marten, 'Port State Jurisdiction in New Zealand: The Problem with Sellers' (2013) 44 Victoria University of Wellington Law Review 559-572; Molenaar (n 52) at 231-232; Serdy (n 69) at 26-33. For support of the court's reasoning: JS Davidson, 'Freedom of Navigation on the High Seas: Sellers v. Maritime Safety Inspector' (1999) 14 International Journal of Marine and Coastal Law 435-439; Devine (n 51). New Zealand Police v. Teddy [2013] NZHC 432, affirmed this EFSJ interpretation.

87 Marten (n 86) at p. 566 points to the Court correctly emphasising EFSJ, before suggesting that the provision was legally territorial. This suggests that if it was not, it might be an issue.

88 As seen by coastal state creeping jurisdiction debates: R Warner and R Rayfuse, 'Securing a Sustainable Future for the Oceans beyond National Jurisdiction: The Legal Basis for an Integrated Cross-Sectoral Regime for High Seas Governance for the 21st Century' (2008) 23 The International Journal of Marine and Coastal Law 399-421, at p. 408. One such interest is the "common economic interest in maintaining respect for rules protecting their shipping and trade through affording all others the same protections"; D Guilfoyle, Shipping Interdiction and the Law of the Sea (Cambridge University Press, Cambridge, 2009) at p. 16. 
The essence of these theoretical debates rests on the content of 'exclusive flag state jurisdiction'. As will now be seen, one interpretation removes the troubles alluded to, and it is suggested that the principle is restrictively discussed in future literature-particularly in relation to port states where it has little or no relevance.

\section{Exclusive Flag State Jurisdiction}

As demonstrated, EFSJ has been suggested in a number of scenarios as being a legal limitation on otherwise valid state jurisdiction in connection with activity on the high seas. Discussions on port state jurisdiction have not escaped this trend. This part argues that the EFSJ principle is solely concerned with enforcement jurisdiction exercised on the high seas (and in the EEZ, as applicable). When restrictively interpreted, which as a limitation on state jurisdiction and sovereignty it should be, ${ }^{89}$ the principle appears to be a red herring for the jurisprudence and literature on maritime jurisdiction. It neither entails exclusive prescriptive jurisdiction for the flag state (France: SS Lotus), nor exclusive flag state enforcement jurisdiction in relation to (as opposed to on) the high seas (Italy: Enrica Lexie). We review the conditions 'exclusive' and 'jurisdiction', in turn, to reach as accurate an interpretation of EFSJ as possible.

\section{'Exclusive'}

Article 92 is not the only 'exclusive' jurisdiction provided for in the LOSC. Coastal states are also granted exclusive jurisdiction in relation to artificial islands, installations and structures. ${ }^{90}$ Clearly, 'exclusive' certainly provides primacy, to the effect that the 'exclusive' state shall have the right to apply its jurisdiction, to the detriment of any other state who might have had the right to concurrent jurisdiction. In regard to Article 92, the qualification "save in exceptional cases

89 One could equally link this to the object and purpose of the LOSC as evident in the Preamble, which repeatedly refers to the equality of all states, and to the recognition of the sovereignty of all states, in establishing a legal order for the seas in line with UN Charter principles (which repeat these general principles). It is universally suggested that other exceptions to the jurisdiction of maritime states are restrictively interpreted, unless linked to another object and purpose of the LOsc, such as protection of the freedoms of the seas. In the interest of equality and neutrality between the contracting flag and non-flag parties, a similar approach should be taken to EFSJ — which, as is evident below, can fulfil its function of preserving navigational freedom through limiting enforcement jurisdiction only. 
expressly provided for in international treaties or in this Convention", means that this rule of primacy operates as a rebuttable presumption. Therefore, flag state jurisdiction shall apply as a limitation on another's jurisdiction, unless one of the 'exceptional cases' applies, or the state can establish that a new exception has emerged. As Rayfuse highlights, the "burden of establishing such contrary rules or exceptions will, however, be high". 91

As a limitation, it is theoretically possible that a relationship could be established between extra-territorial port state jurisdiction rights, and flag state exclusivity limitations. However, due to the scope of 'jurisdiction' in Article 92, it is suggested that no such relationship exists, and it is here that differing interpretations arise.

\section{'Jurisdiction'}

"A reading of the Convention on the High Seas in its pristine, black-letter absolutism would be seriously misleading with respect to the balance actually provided in international law for allocation of the competence to apply authority."92

The treaty articles on EFSJ are not only misleading in respect of the lack of reference to customary law exceptions (MacDougal and Burke), but also through their use of the term 'jurisdiction' without qualification or definition. Jurisdiction terminology is used throughout international law, often for different purposes and with different meanings. ${ }^{93}$ If you accept this paper's position, this is so even in the LOSC, where the unrefined term 'jurisdiction', as a flag state duty, is wider than exclusive jurisdiction as a right (because Article 94(3)-(4) entails prescriptive duties, whilst Article 92 only entails enforcement exclusivity). It is likely that suggestions that EFSJ includes prescriptive exclusivity, or that the mere extra-territorial prescription by port states will weaken flag state exclusivity, are based on an absolute interpretation of Article 92.

However, as is convincingly covered and stated by arguably the majority in academia, the 'jurisdiction' of exclusive jurisdiction concerns enforcement

91 R Rayfuse, Non-Flag State Enforcement in High Seas Fisheries (Martinus Nijhoff Publishers, Leiden, 2004), at p. 22.

92 MS MacDougal and WT Burke, The Public Order of the Oceans: A Contemporary International Law of the Sea (Martinus Nijhoff Publishers, Dordrecht 1987), at p. 875 .

93 See, "Jurisdiction as a concern of International Law", Ryngaert (n 7) at pp. 5-10; Y Xiaodong, 'Jurisdiction', in A Carty, Oxford Bibliographies in International Law (Oxford University Press, Oxford, 2012), available at http://www.oxfordbibliographies.com/view/ document/obo-9780199796953/obo-9780199796953-0030.xml, accessed зo May 2016. 
jurisdiction only. ${ }^{94}$ Several authors are explicit in this regard. ${ }^{95}$ For others, it can be implicitly taken from the way in which they discuss the exceptions, as exceptions to a prohibition on the exercise of extra-territorial enforcement. ${ }^{96}$ This is also recognisable in case law, such as the Arctic Sunrise Arbitration, although not explicit. ${ }^{97}$ Article 92 is simply silent on non-flag state prescription. ${ }^{98}$

94 Guilfoyle (n 88) at pp. 2, 276-277; R Reuland, 'Interference with Non-National Ships on the High Seas: Peacetime Exceptions to the Exclusivity Rule of Flag-State Jurisdiction' (1989) 22 Vanderbilt Journal of Transnational Law 1161-1229. "In this sense the principle of the "exclusive jurisdiction" on the flag State can mislead those unfamiliar with the law of the sea", D Guilfoyle, 'Shooting fishermen mistaken for pirates: jurisdiction, immunity and State responsibility' Ejil:Talk! Blog (02.03.2012), available at http://www .ejiltalk.org/shooting-fishermen-mistaken-for-pirates-jurisdiction-immunity-and-stateresponsibility/, accessed 30 May 2016.

95 D Guilfoyle, 'The High Seas', in Rothwell et al. (n 12) 203-225, at pp. 209-210; Akehurst (n 6o) at p. 187; RK Gardiner, International Law (Pearson Education Limited, Harlow, 2003), at p. 405; D Guilfoyle, 'Interdicting Vessels to Enforce the Common Interest: Maritime Countermeasures and the Use of Force' (2007) 56 International and Comparative Law Quarterly 69-82, at pp. 80-81; N Klein, Maritime Security and the Law of the Sea (Oxford University Press, Oxford, 2011), at pp. 105-146; Rayfuse (n 91) at p. 43; T Smith, 'Fighting on the Ocean Blue: New Zealand's Extra-Territorial Jurisdiction and Maritime Protest' (2001) 32 Victoria University of Wellington Law Review 499-520, at p. 502; F Orrego Vicuña, The Changing International Law of High Seas Fisheries (Cambridge University Press, Cambridge, 1999) at p. 240. "Maritime security is not comprehensively dealt with in UNCLOS although it sets out a clear jurisdictional framework for enforcement against crimes at sea", R Beckman and T Davenport, 'The EEZ Regime: Reflections after 30 Years', in HN Scheiber and MS Kwon (eds), LOSI Conference Papers (Berkeley Law School, Berkeley, CA, 2013) at p. 20. R Rayfuse, 'The Role of Port States', in Warner and Kaye (n 32) 71-85, at p. 71; Roach and Smith (n 21) at ch. 20, p. 562 (EFSJ in relation to enforcement).

96 AL Kolodkin, VN Gutsuliak and I Bobrova, The World Ocean: International Legal Regime (Eleven International Publishing, The Hague, 2010), at pp. 139-140, 24-25; DR Rothwell and T Stephens, The International Law of the Sea (Hart Publishing Limited, Oxford, 2010), at pp. 160, 146 (discussing Art. 92 and nationality jurisdiction); M Shaw, International Law (7th ed., Cambridge University Press, Cambridge, 2014), at pp. 443-445.

97 "As a result of the exclusive jurisdiction of the flag State over ships in the EEZ, a coastal State may only exercise jurisdiction, involving law enforcement measures, over a ship, with the prior consent of the flag State. This principle is subject to exceptions, some of which are discussed below" [discussion only looks to enforcement/boarding] The Arctic Sunrise Arbitration (n 18) at p. 55, para. 231. See also the 'AdvanFort' dispute discussed by J Kraska, 'Excessive Coastal State Jurisdiction: Shipboard Armed Security Personnel', in Ringbom (n 31) 167-193, at p. 184. Additionally: Dissenting Opinion of Judge Cot, (n 56 ) at 97-98, paras. 21-24.

98 Enforcement jurisdiction, "To be distinguished from a state's jurisdiction to prescribe, which is not regulated by UNCLOS but by the general law" J Crawford, Brownlie's Principles 
If one looks beyond the wording of Article 92, to the zonal system of Part VII, it is evident that EFSJ is solely concerned with enforcement. Article 92 refers to the exceptions "expressly provided for", but in the LOSC these are exceptions of an enforcement nature, notably Articles 105 (piracy), 109(4) (unauthorized broadcasting), 110 (right of visit, in respect of defined activities), 111 (hot pursuit), 221 (maritime casualties or "related" acts, reasonably expected to result in major harmful consequences), and 220(3-6) (various degrees of EEZ pollution).${ }^{99}$ In the fisheries context, additional examples may be found in the Fish Stocks Agreement, Articles 21 and $22 .{ }^{100}$ As treaty-based rights to high seas enforcement, these are expressly provided for as such. ${ }^{101}$ This is in notable contrast to non-flag jurisdiction in relation to, but not enforced upon, the high seas, such as port states in Article 23, which have a right to jurisdiction under customary international law, and expressly not the LOSC. ${ }^{102}$

By way of example, the primacy of enforcement in these principles is evident when one reviews the hot pursuit exception, which provides for extended coastal state enforcement jurisdiction onto the high seas. Unlike other examples of non-flag jurisdiction, it provides no right of high seas

of Public International Law (Oxford University Press, Oxford, 2012), at p. 301, fn. 26. "The alterative, of course, [to jurisdiction under Losc] is to rely on general principles of prescriptive jurisdiction under public international law and use them to criminalise acts occurring at sea”, D Guilfoyle, 'Transnational Crime', in Warner and Kaye (n 24) 262-276, at p. 264 .

99 Although one commentary to Article 92 goes beyond the exceptions of Part VII, the focus is still largely on non-flag enforcement (Arts. 27, 28, 73, 246), Nordquist et al. (n 18) at p. 126. Whereas Article 42, which provides prescriptive jurisdiction, is listed, enforcement jurisdiction is provided under Article 233 .

100 Agreement for the Implementation of the Provisions of the United Nations Convention on the Law of the Sea of 10 December 1982 relating to the Conservation and Management of Straddling Fish Stocks and Highly Migratory Fish Stocks (New York, 4 December 1994, in force 11 December 2001) (Fish Stocks Agreement) 2167 UNTS 3.

101 C Hedley, AG Elferink and EJ Molenaar, The Implications of the UN Fish Stocks Agreement (New York, 1995) for Regional Fisheries Organizations and International Fisheries Management, Working Paper, Fisheries Series (Fish 112 En, o1-2004), European Parliament, Directorate-General For Research (Luxembourg, European Parliament: 2003), at p. 37, available at http://www.europarl.europa.eu/RegData/etudes/etudes/join/2003/337297/ IPOL-PECH_ET(2003)337297_EN.pdf, accessed 30 May 2016.

102 Fish Stocks Agreement, Article 23(4): "Nothing in this article affects the exercise by States of their sovereignty over ports in their territory in accordance with international law"; PSMA, Article 4(1). This is admittedly subject to an interpretative debate beyond the scope of this article, Molenaar (n 11) paras. 29-30. 
prescription (which the other exceptions presuppose). ${ }^{103}$ Hot pursuit is established on the basis of violation(s) of territorial, or quasi-territorial, or functionally proscribed laws that are applicable to maritime zones under national jurisdiction. It is an 'exceptional', and clearly defined, right of enforcement on the high seas. As an exception to exclusive flag state enforcement, it extinguishes at the boundaries of exclusive flag state enforcement jurisdiction, i.e., foreign territorial waters. ${ }^{104}$ If flag state enforcement flows from its sovereignty, 105 and non-flag enforcement from consent, a flag state cannot provide a jurisdictional right exception greater than its own authority, and thus clearly cannot provide for non-flag enforcement in foreign territorial waters, where it has itself no enforcement rights.

What is more, this exclusivity only extends to the exercise of non-flag state enforcement, when exercised on the high seas. ${ }^{106}$ Port states could therefore by definition not raise any legal relationship with EFSJ, whether prescribing or enforcing. ${ }^{107}$ The exclusivity principle attaches to the location of the vessel, and is therefore not only limited spatially (high seas), but temporally (when sailing 'on' the high seas). In contrast, the exercise of enforcement jurisdiction is spatially and temporally defined, for the purposes of analysing state enforcement jurisdiction, by the enforcement action (port state measures exercised in the internal waters), at the time of enforcement (when the vessel is located in internal waters). The location of the prohibited conduct by the vessel is irrelevant for the purposes of enforcement jurisdiction.

Thus the port state could exercise extra-territorial prescription, such as provided by Article 218, and be prohibited from taking any enforcement measures against the vessel whilst it is on the high seas. However, once in the port state territory, the EFSJ principle no longer applies, and enforcement can occur. This is why, strictly speaking, extra-territorial port state jurisdiction, of a residual, or Article 218 based nature, should not be treated as an 'exception' to flag

103 Described as 'fundamentally different': EJ Molenaar, 'Multilateral Hot Pursuit and Illegal Fishing in the Southern Ocean: The Pursuits of the Viarsa 1 and the South Tomi' (2004) 19 The International Journal of Marine and Coastal Law 19-42, at p. 24.

104 LOSC Article 111.

105 Kraska and Pedrozo (n 43) at p. 365.

106 This is evident in the exceptions, which discuss enforcement 'on' the high seas. Also, " $[\mathrm{t}]$ he sui generis nature of the exclusive economic zone led to the conclusion that the Convention should not attempt to define the "high seas," but instead should indicate the application ratione loci of the provisions relating to the high seas", Nordquist et al. (n 18) at p. 32 .

107 It could nevertheless conflict with general flag state jurisdiction, if exercised without a legal basis. 
state exclusivity. ${ }^{108}$ This was captured by Rayfuse in her work on non-flag state enforcement, and the distinction of port state enforcement from other direct enforcement actions on the high seas. ${ }^{109}$

This conclusion is supported by the Losc, and other treaties, which implicitly, or explicitly suggest extra-territorial prescriptive jurisdiction on the high seas in addition to any high seas enforcement exceptions. ${ }^{110}$ If EFSJ were to include prescription, the wording, 'persons subject to its jurisdiction', when discussing prescriptive jurisdiction over damage to submarine cables and pipelines, could hardly be seen as an explicit 'exception'.111 Subsequent practice would include the Convention for the Suppression of Unlawful Acts against the Safety of Maritime Navigation (sUA), which, by placing legislative obligations on state parties, implies prescriptive jurisdiction in relation to high seas conduct. ${ }^{112}$ This includes passive personality $(6(2)(b))$, nationality $(6(1)(c))$ and protective jurisdiction $(6(2)(\mathrm{c}))$, whilst safeguarding exclusive high seas flag state enforcement. ${ }^{113}$ Another example could be the PSMA, which calls on states to "use all available jurisdiction in accordance with international law" to combat IUU fishing. ${ }^{114}$

Finally, undisputed state practice, prescribing laws for vessels or crew, including on the high seas, has followed suit. ${ }^{115}$ It is subsequent practice

108 Nordquist et al. (n 18) point to developments in enforcement jurisdiction representing a departure from EFSJ. However, in-port enforcement (at pp. 218-220) is also discussed as such (at pp. 126-127) and listed as an exception to the prohibition of exclusivity; ibid., at p. 169 .

109 "It is arguable that port state enforcement is not an aspect of non-flag enforcement but is simply an aspect of the right of all coastal states to control activities within their territory", Rayfuse (n 91) at p. $5^{2}$.

110 LOSC Articles 117 (nationals); 109 (flag; state of installation registry; nationals; where the transmissions can be received; where authorized radio communication is suffering interference).

111 LOSC Articles 113-114.

112 Convention for the Suppression of Unlawful Acts against the Safety of Maritime Navigation (Rome, 10 March 1988, in force 1 March 1992) 1678 UNTS 201, Article 4.

113 SUA, Article 9; "Nothing in this Convention shall affect in any way the rules of international law pertaining to the competence of States to exercise investigative or enforcement jurisdiction on board ships not flying their flag".

114 PSMA, Preamble, para. 3 .

115 For a few nationality principle examples: Australian practice, in particular The Crimes at Sea Act 200o; House of Representatives Standing Committee on Social Policy and Legal Affairs, 'Jurisdiction at sea: international law and domestic law', Troubled Waters: Inquiry Into The Arrangements Surrounding Crimes Committed At Sea (June 2003, Canberra) at 21-39; usa Practice, discussed: S. Hernandez, 'Crimes Against Americans on Cruise Ships', 
involving at-sea enforcement that is viewed as novel exceptions. ${ }^{116}$ When the issue has been raised in discussions at international organisations, a restrictive interpretation of EFSJ is applied. This can be seen in a Japanese submission before the Legal Committee of the International Maritime Organization, where a lack of domestic legislation was the discussion point of inadequate responses to high seas crimes committed aboard foreign-flagged vessels. ${ }^{117} \mathrm{~A}$ right to prescriptive jurisdiction is presupposed, and the proposal considers whether enforcement obligations should be imposed on non-flag states, notably port and coastal states. ${ }^{118}$

\section{Article 97: Exception that Proves the Rule}

Unlike the EFSJ exceptions discussed above, which grant enforcement jurisdiction, LOSC Article 97 limits enforcement jurisdiction in relation to collisions and 'incidents of navigation' on the high seas. ${ }^{119}$ As it is not concerned with at-sea enforcement, it is not an exception to EFSJ, but rather demonstrates the position of extra-territorial prescription (in relation to high seas conduct), territorially enforced. It thus provides supporting evidence for two reasons.

First, although Article 97(1) explicitly discusses nationality (i.e., non-flag state) jurisdiction, this is as a limitation on other non-flag states, and not as an exception to Article 92; "no penal or disciplinary proceedings may be instituted against such person except before [...]". ${ }^{120}$ If EFSJ included prescriptive jurisdiction, Article 97 would be superfluous, as no such right would exist for

Statement before the House Committee on Transportation and Infrastructure, Subcommittee on Coast Guard and Maritime Transportation, 27 March 2007, available at https://www.fbi .gov/news/testimony/crimes-against-americans-on-cruise-ships, accessed 30 May 2016. Nationality principle discussion, with UK practice: Guilfoyle (n 95) at pp. 209-210.

116 Examples: Nordquist et al. (n 18) at pp. 36, 126.

117 Japan, Discussion on the measures to protect crews and passengers against crimes on vessels, IMO LEG 85/10, 29 August 2002 (available at www.imo.org.). The responses from other states suggested; "there are a substantial number of States that would act under national and customary international law in a manner similar to what would be required under the suA Convention if it were applicable", Comité Maritime International, Yearbook 2003, at p. 585, available at http://www.comitemaritime.org/Uploads/Yearbooks/YBK_2003.pdf, accessed 30 May 2016.

118 Explicit in this regard in subsequent submissions; Comité Maritime International, Yearbook 2004, at pp. 344-345, para. 5(c), available at http://www.comitemaritime.org/ Uploads/Yearbooks/YBK_2004.pdf, accessed 30 May 2016.

119 LOSC Article 97; HSC, Article 11; International Convention for the Unification of Certain Rules relating to Penal Jurisdiction in Matters of Collision and Other Incidents of Navigation (Brussels, 10 May 1952, in force 20 November 1955) 439 UNTS 233.

120 (emphasis added) Losc Article 97(1). 
other states in the first place. If it was otherwise, surely Article 97 would be framed as a right, consistent with the other provisions of Part VII.

Second, Article 97 confirms that Article 92 is solely concerned with enforcement jurisdiction exercised on the high seas. In Article 97(3) a limitation is imposed on territorial enforcement, in relation to high seas conduct: "no arrest or detention of the ship, even as a measure of investigation, shall be ordered by any authorities other than those of the flag state". ${ }^{121}$ Again, this would be superfluous if EFSJ already limited prescriptive jurisdiction, or territorial enforcement in relation to the high seas. It therefore implies that in cases not related to collisions or other incidents of navigation, non-flag states are not subject to additional limitations under Articles 97 or 92.

\section{The Drafting History and Rationale of EFSJ}

Once codified, the customary principle of EFSJ has had a steady and uniform history. ${ }^{122}$ The International Law Commission (ILC) Draft Articles, Articles 30-31, 'Status of ships' and 'Ships sailing under two flags', ${ }^{123}$ became a single Article 6 with the 1958 HSC. LOSC Article 92 followed, with minimal alteration. ${ }^{124}$

Whereas the Draft Articles themselves do not provide further guidance, ${ }^{125}$ this consistent drafting history, and in particular its commentary, emphasizes the role of EFSJ, and the freedoms of the seas, as the two interlinked and foundational principles of the high seas regime. Part VII is a functional regime, focused on "global navigation and communication" in Section 1, and on natural resources with Section 2. ${ }^{126}$ Apart from Article 117, all provisions discussed

\footnotetext{
121 LOSC Article 97(3).

122 HSC, Preamble, "generally declaratory of established principles of international law"; applicable to Part VII(1), Nordquist et al. (n 18) at pp. 27-28.

123 International Law Commission, 'Articles Concerning the Law of the Sea with Commentaries', Yearbook Of The International Law Commission, 1956, Vol. II 265-301, at pp. 279-280, available at http://legal.un.org/ilc/texts/instruments/english/commentaries/ 8_1_8_2_1956.pdf, accessed 30 May 2016.

124 "the present convention" replacing "these articles".

125 Perhaps one could suggest that the consolidation of the ILC Draft Articles LOS, Articles 30-31, into a single Article means that one could look at the position of ships without nationality (Art. 92(2)), when interpreting Article 92. The 'punishment' for flagless vessels is the loss of protection of a flag state, which entails the right of other states to exercise certain enforcement powers against that vessel on the high seas. However, given the suggestion that a link between the vessel and the state in question is required, it clearly does not have an effect on prescriptive jurisdiction. This would suggest that EFSJ is only concerned with protection from non-flag state enforcement jurisdiction.

126 Nordquist et al. (n 18) at p. 27.
} 
above are found in Section 1 and thus the central focus of EFSJ is the protection of the freedoms for all states. As Poland submitted in 1955, before discussing enforcement exceptions, "[f]rom the principle of freedom of the seas it follows that only the state to which a given ship belongs has the right to extend its jurisdiction over it on the high seas". ${ }^{27}$ This is reiterated in the ILC Commentary; "The absence of any authority over ships sailing the high seas would lead to chaos. One of the essential adjuncts to the principle of the freedom of the seas is that a ship must fly the flag of a single State and that it is subject to the jurisdiction of that State". ${ }^{128}$

The ILC Commentary similarly points to at-sea enforcement exceptions. ${ }^{129}$ Clearly, unrestricted enforcement on the high seas, where no territorial state has exclusive enforcement jurisdiction, would have seriously undermined the exercise of such freedoms. In the interests of the international community, enforcement jurisdiction has been vested exclusively with the flag state, subject to internationally recognised exceptions. But, assuming this is not exhaustive, is there anything in this rationale of EFSJ to suggest that exclusive jurisdiction extends beyond non-flag enforcement on the high seas?

When one looks to the freedoms, their scope only rationalises a limitation on non-flag state high seas enforcement. To go further would require evidence that the freedoms contained in Article 87 extended beyond enjoyment on the high seas maritime zone. Yet the ITLOS has consistently ruled to the contrary, stating that Articles 87 and 90 only apply on the high seas. ${ }^{130}$ In the port state

127 Observations of the Government of Poland, concerning freedom of navigation on the high seas, A/CN.4/L.53, 1[4], available at http://legal.un.org/docs/?path=../ilc/documentation/english/a_cn4_153.pdf\&lang=E, accessed 30 May 2016. Additionally China (suggesting the application of general principles for jurisdiction); Transmitted by A Letter Dated 9 February 1956 From the Permanent Mission of China to the United Nations, A/CTS.4/99, 43[1], available at http://legal.un.org/docs/?path=../ilc/documentation/english/a_cn4_99. pdf\&lang=EFS, accessed 30 May 2016.

128 See ILC Draft Articles LOS, at p. 279. Academic examples include: Hoffmann (n 30 ) at parts $\mathrm{F}$ and $\mathrm{H}$; "The main objective of this rule is to confer an immunity on vessels exercising freedom of navigation on the high seas from interference by the public vessels of foreign states", Guilfoyle (n 98) at p. 263.

129 ILC Draft Articles LOS, at p. 279.

130 Article 87 only applies to the high seas/EEZ; The M/V "Lousia" Case (Saint Vincent and the Grenadines v. Spain) (Provisional Measures), Order of 23 December 2010, Case No. 18, at p. 34, para.109 (ITLOS 2010), available at https://www.itlos.org/fileadmin/itlos/documents/ cases/case_no_18_prov_meas/18_order_231210_en.pdf, accessed 30 May 2016. Declaration Of Judge Paik, Case No. 18, at p. 9, paras. 28-29, available at https://www.itlos.org/filead$\mathrm{min} /$ itlos/documents/cases/case_no_18_merits/judgment/C18_Judg_28_05_2013_Decl_ Paik_E_orig.pdf, accessed 30 May 2016; Dissenting Opinion Of Judge Lucky, Case No. 18, 
context, the freedoms provide no "right to leave the port and gain access to the high seas". ${ }^{131}$ Indeed quite the opposite is true. A lack of extra-territorial prescription applicable to the high seas, and enforced, e.g., by port states, has been raised as having 'negative effects' on the global maritime transport sector, i.e., the sector such freedoms are supposed to benefit in the interests of all. ${ }^{132}$

Therefore, although sufficient evidence exists for the conferral of absolute jurisdiction on flag states, and, subject to recognised exceptions, an exclusive right to enforcement on the high seas, no rationale is found for the interpretations of EFSJ proposed in the first half. It would, after all, be on the state additionally claiming exclusive prescription and/or exclusive territorial enforcement in regard to the high seas to demonstrate that such a limitation on the jurisdiction of other states existed.

\section{Conclusion}

"While international lawyers often employ the term 'jurisdiction,' and most of them have an inkling of what it means, defining jurisdiction is hardly self-evident". 133

The difficulty, and resulting dangers, are two-fold when discussing the relationship between concurrent jurisdictions. This has been witnessed with 'exclusive flag state jurisdiction', and its staying power as a relevant factor for consideration in limitations to port state extra-territoriality, or the

at p. 9, paras. 35-37, available at https://www.itlos.org/fileadmin/itlos/documents/cases/ case_no_18_merits/judgment/C18_Judg_28_05_2013_DissOp_Lucky_E_orig.pdf, access 30 May 2016; Dissenting Opinion Of Judge Wolfrum (Provisional), Case No. 18, at pp. 83-84, para. 22, available at https://www.itlos.org/fileadmin/itlos/documents/cases/case no_18_prov_meas/18_order_231210_dis_op_Wolfrum_en.pdf, accessed 30 May 2016. The "ARA Libertad" Case (Argentina v. Ghana), Order of ${ }_{15}$ December 2012, Case No. 20, at p. 15, para. 61 (ITLOS 2012), available at https://www.itlos.org/fileadmin/itlos/documents/ cases/case_no.20/C20_Order_15.12.2012.corr.pdf, accessed 30 May 2016. Joint Separate Opinion Of Judge Wolfrum And Judge Cot, Case No. 20, at pp. 12-13, para. 37, available at https://www.itlos.org/fileadmin/itlos/documents/cases/case_no.20/C20_Ord_15.12.2012_ SepOp_Wolfrum-Cot_E_corr.pdf, accessed 30 May 2016. Contra see; Separate Opinion Of Judge Lucky, Case No. 20, at p. 6, para. 29, available at https://www.itlos.org/fileadmin/ itlos/documents/cases/case_no.20/C20_Ord_15.12.2012_SepOp_Lucky_E_orig-no_gutter. pdf, accessed 30 May 2016.

131 The $M / V$ "Lousia" case (n 130) at p. 34, para. 109.

132 IMO LEG 85/10 (n 117), at p. 2, para. 5; p. 3, para. 6(c)(ii).

133 Ryngaert ( $\left.\mathrm{n}_{7}\right)$ at p. 15. 
evolutionary effects of increasing port state practice. This is despite the PCIJ's dismissal of the issue in this context, some 88 years ago.

So what does EFSJ mean for port states? Apart from the very restricted exceptions of Article 97, and cases of immunity, ${ }^{134}$ there is no formal conflict of laws. The port is left with almost unlimited legal discretion by the LOsC. Unlike coastal states, which in return for jurisdictional rights had to accept significant jurisdictional limitations, for the benefit of flag states and the broader international community, port states look to general principles of jurisdiction for power. Should ports be able to squeeze regulation into the loosely defined principles of jurisdiction, a flag state will find no solace in raising EFSJ.

And what does port state jurisdiction mean for flag state jurisdiction? Talk of EFSJ in this context is a red herring, and for the sake of legal clarity should be avoided. As a distinct legal principle, inapplicable in the port state context, it is unhelpful to raise this as being weakened by PSJ, or to weaken extraterritorial PSJ. The increase in concurrency of jurisdiction will not be felt in the international law discussed, but rather factually in the flag-port power balance, and in the lives of vessel operators. ${ }^{135}$ The historical presumption that only flag state law applies will be eroded, as port states decide to dispense with previous considerations of comity, and to regulate extra-territorial conduct and increase their influence on behaviour around the globe.

Perhaps it is rather peculiar to write an article on port state jurisdiction and EFSJ that argues that we need not discuss port state jurisdiction and EFSJ together. But it is hoped that by doing so others will not fall into the same difficulties experienced by the author in trying to reconcile mutually exclusive legal principles. Better clarity is required on both fronts. Discussions of EFSJ should be more restrictively applied. It appears that no limitation on the prescriptive jurisdiction of other states is inferred, and no limitation on the exercise of territorial enforcement is inferred-no matter what the high seas nature of the act is, or the actor's flag state. Port state literature needs equal clarity, not raising a legal term which is largely irrelevant and perhaps

134 This is beyond the scope of this article, but it is nonetheless a relevant exception.

135 They after all may need to be aware of the potentially applicable legal regimes of their flag state, the port of disembarkation, any future ports of arrival (indefinitely?), coastal state, state of nationality, etc. For an example of a lack of appetite by the shipping industry for unilateral port state measures, see discussions surrounding Regulation (EU) 2015/757: $\mathrm{N}$ Dobson, 'Going it alone-the EU adopts its own maritime emissions monitoring scheme as the Imo lags behind', Renforce Blog (13.08.2015), available at http://blog.renforce.eu/index.php/nl/2015/10/13/going-it-alone-the-eu-adopts-its-own-maritime-emissions-monitoring-scheme-as-the-imo-lags-behind-2/, accessed 30 May 2016. 
over-emphasising the innovative effects of expansive port state jurisdiction. If one cannot look to this Losc limitation as a jurisdictional 'brake', the true debate is much more fundamental: what is the scope of the jurisdictional rights of the port state in the first place, and what limitations could a flag state raise when challenging perceived abusive territorial jurisdiction? 